University of Warwick institutional repository

This paper is made available online in accordance with

publisher policies. Please scroll down to view the document

itself. Please refer to the repository record for this item and our

policy information available from the repository home page for further information.

To see the final version of this paper please visit the publisher's website. Access to the published version may require a subscription.

Author(s): Stuart Croft

Article Title: Religion and foreign policy

Year of publication: 2009

Link to published version: http://www.renewal.org.uk/

Publisher statement: None 


\section{Religion and foreign policy}

\section{Stuart Croft}

Religion has become (again) a recognisable significant factor in many aspects of international politics. Any consideration of its role inevitably raises in the mind of the British reader the current threat of terrorism from 'Al Qaida and related terrorist groups' as MI5 puts it (1). For reasons that I will return to later, this 'international terrorism' is not labelled as being in any sense related to, or derived from Islam officially in the British language MI5 describes the threat as being not even from readings of Islam, but rather from 'AI Qaeda's ideology' (2). But all recognise this terrorist threat as being related in some form to religion. The attacks on New York and Washington, Bali, Istanbul, London, Madrid - have all brought into sharp relief the mobilising effect of religion. But religion is not only important in the twenty-first century because of those terrorist acts and threats.

\section{Religion in America}

For many in the UK, our view of American religion is of something quirky, taking place in those parts of the United States that we don't visit, and certainly not shared by our American friends and colleagues.

We often focus on the drive for creationism, or to be more accurate, the commitment to 'Intelligent Design', the view that God did create the universe, and that Darwin was wrong. With echoes of the Scopes trial of 1925, when the state of Tennessee forbade the teaching of science that denied the literal truth of the Bible in our minds, we construct such religious views as being marginal to American life, even crazy. A conventional example is the so-called Westboro Baptist Church (although they have no formal links to the Baptist hierarchy) who proclaim views from their website with an extraordinary title (3).

Yet we are wrong just to focus on the margins. Tens of millions of dollars are spent each year on developing an alternative to the theory of evolution. In Seattle, the Discovery Institute works to develop an alternative; they proclaim the peer reviewed scientific articles that justify Intelligent Design (4); a mission also followed at Answers Research Journal - a 'a professional, peer-reviewed technical journal for the publication of interdisciplinary scientific and other relevant research from the perspective of the recent Creation and the global Flood within a biblical framework' (5). Lee Strobel's book The Case for a Creator: $A$ Journalist Investigates Scientific Evidence That Points Toward God, was a best seller, emphasising the point that debate has been joined at a different level (Strobel, 2005).

And then there are the popular cultural dimensions. Look for example at Paw Creek Ministries, where we learn that Harry Potter is a vision of the Antichrist. Pastor Joseph Chambers writes that 'The Harry Potter book reveals a very enlightening picture of the coming days for those "left behind" after the Rapture of the saints' (6). Such views may represent very few; and yet they are important, as they draw on a wider American conservative discourse. 
RENEWAL Vol 17 No. 12009

Chambers' talk of those 'left behind' after the Rapture has a wide resonance. In this view of the 'end times' (that is, of the Second Coming), the believers are 'Raptured' (lifted to Heaven) to avoid the battle with the Antichrist. The theme is a cultural phenomenon in the United States. Tim LaHaye and Jerry B. Jenkins' books, the Left Behind series, have sold over seventy million copies in the US. Films of the series are launched not in cinemas, but in churches; and the third movie, in 2005, was released simultaneously in 3,200 noncommercial outlets (Cooperman, 2005). Left Behind is even a computer game, despite many on the Christian Right being against such games (7).

The Rapture is a serious proposition amongst the conservative right; the conservative Swift Report reported in 2004 that 6 June 2006, otherwise known as '666' or 'Mark of the Beast' day, is cause for celebration among Satanists, teacher unions and in the nation's godless urban centres. But among key Bush administration figures there was great concern that the day could mark the start of 'The Rapture', in which President Bush and millions of other Christians are summoned up to heaven (Swift, 2004). Oh, and in case you were wondering, the report continued with the line: 'Most Democrats likely to be left behind'.

Perhaps, then, we should accept that there is a cultural impact, particularly in conservative America, for religious views that have very little resonance or understanding in Europe. Christianity is an important part of the American identity; the Roper Center lists a series of 2006 polls which show that 84 per cent personally believe that Jesus is the Son of God; and that 82 per cent answered a separate poll that they believed in God (8). The latest highly detailed Pew Forum on Religion and Public Life survey shows a 78.4 per cent Christian population (Pew Forum, 2008). The majority of Americans have Christianity as part of their identity and as part of their discourse.

\section{The impact on foreign policy}

In terms of impacts upon the development of US foreign policy, it is perhaps inevitable that there should be significant political forces arguing for the introduction of God. Democrats have often sought to resist these politics. Madeleine Albright, the former Secretary of State, has written of the determined efforts of the Clinton administration to keep religion out of their assessments of major challenges, such as the Balkans, Israel-Palestine, and the 1998 bombings of embassies in Africa by Al-Qaeda (Albright, 2006). But with the advent of a religious President, and the rise in the focus on faith issues after 11 September 2001, religion is on the US political agenda.

In fact, it has been for years. Despite the Clinton administration's reserve on religion, the International Religious Freedom Act of 1998 made the provision of religious freedom a core aim of American foreign policy, to be monitored and promoted by the State Department. One of the key targets for the Christian Right has been to support Christians in Sudan; they secured the passage of the Sudan Peace Act in 1999, and another in 2002, along with the North Korea Human Rights Act of 2004.

So what do Christian right organisations seek to achieve in changing American foreign policy? For change is their goal; although there have been important alliances with the Bush Administration, there have also been significant differences: the Christian right differ with neo-conservatives on a number of points, mostly 'issues of conscience'.

Although there are many Christian organisations, on foreign policy issues there is 
something of a consensus around the need to replace the 'war on terror' with a commitment to Christian solidarity. An alliance of convenience cannot override the need to support the persecuted in countries such as Pakistan, Saudi Arabia and Uzbekistan. That there has been a 'war on terror' should not, in their view, absolve the US government from its duty to protect Christians in such allied countries. Second, that international institutions - such as the UN or the EU - can only be used tactically to pursue key social goals globally: hostility to birth control and the use of condoms in combating AIDS; support for measures to 'strengthen the family'; hostility to recognition of gay rights (see Buss and Herman, 2003). In this, of course, they have been content to form alliances with conservative Islamic forces. And third, a stronger commitment to Israel, with all that implies for any roadmaps, as the focal point for the Second Coming (for more on all these points, see Croft, 2007).

This may seem pretty negative from the perspective of those committed to progressive politics in Europe; and indeed, in many ways it is. US Administrations of whatever hue are likely to be put under significant domestic pressure from these directions, regardless of who is in office, as the next Administration seeks to plot a course away from the dead end that is the 'war on terror' strategy.

But it need not all be negative. The Christian movement in the US has both liberal and conservative wings. The election of Rev. Frank Page as the President of the Southern Baptist Convention might also signal a wider move towards a more engaged politics (see Dionne, 2006). In any case, the American Christian movement has powerful voices arguing for social change in the developing world, and for environmental protection (or, as they would put it, for Creation Care). A reading of the National Association of Evangelicals' document, For the Health of the Nation: An Evangelical Call to Civic Responsibility, would provide several possibilities for common cause concerned with global social justice (National Association of Evangelicals, 2004). As Walter Russell Mead argues, there is a commitment to working across sectarian lines amongst some of the evangelical groups, and that commitment is worth engagement and worth testing (Mead, 2006).

\section{Religion and terrorism}

For many, a title such as this automatically connects the discussion to the minority of those who profess the Islamic faith and commit terrorist acts in its name. But we ought to consider the wider canvas. Some nine hundred members of the Peoples' Temple, a new religious movement, died in Jonestown Guyana in 1978; Aum Shinrikyo, another new religious group, conducted a terror campaign in Tokyo, including the attempted use of nerve gas on the underground system. In 2000, nearly eight hundred members of the Movement for the Restoration of the Ten Commandments of God, a Catholic inspired group, died in murders and suicides in Uganda (Walliss, 2007).

Then there are more conventional American Christian terrorist groups. For example, Timothy McVeigh, who killed 168 people and injured 800 in the Oklahoma City bombing in 1995, was a member of the Christian Patriots. Jason Hamilton, who killed three in 2007, did so to further the cause of the Aryan Nations. James Kopp killed a doctor in 1998 as part of the anti-abortion cause of the Lambs of Christ. In 1995, a train was attacked and derailed in Arizona, killing only one of the 228 passengers. The attack was apparently carried out by 
RENEWAL Vol 17 No. 12009

the Sons of Gestapo, although the group is unknown - it may have been a cover for another group, or a splinter from another group. Eric Robert Rudolph bombed the 1996 Olympics, and killed and injured across the southern United States to oppose abortion and gay rights. He was a sympathiser of the White Supremacist group, Christian Identity.

Inevitably, the use of terrorism in the name of American Christianity unnerves the vast majority of American Christians, and they seek to understand the phenomenon, and to find ways of describing these terrorists as un-Christian. Two contrary views were published in the web version of Christianity Today in 2003, based on a discussion in the Washington Post of the nature of Rudolph's crimes for Christian Identity (Olson, 2003). Syracuse University political science professor Michael Barkun proposes that 'Based on what we know of Rudolph so far ... there seems to be a fairly high likelihood that he can legitimately be called a Christian terrorist', he said. But Idaho State University sociologist James A. Aho disagrees:

I would prefer to say that Rudolph is a religiously inspired terrorist, because most mainstream Christians consider Christian Identity to be a heresy ... The phrase 'Christian terrorist' ... is a sort of an oxymoron.

This exchange between Barkun and Aho is at the heart of the debate about the nature of the relationship between religion and terror. So should the contemporary threat of terrorism being faced by the UK be seen as 'Islamic' terror, or as 'religiously inspired terrorism' because, to appropriate Aho's approach, the violence perpetrated in the name of Islam is itself a 'heresy'?

In some ways, this seems to be a very academic debate; but it is not only an academic debate. It is at the heart of contemporary government policy in the UK. Having conducted extensive focus groups, government has come to the conclusion that there is no term connected to Islam that would give the impression of 'religiously inspired' and not in some sense also signal to some readers that terrorism was a part of Islam. As $\mathrm{Dr} \mathrm{H}$. Hatut expressed it on the website Islamophobia.org:

The term 'Islamic terrorism' is a misnomer because terrorism is the antithesis of Islam, even if terrorists try to camouflage as Islamic and raise Islamic banners and quotations. (Hatut, 2007)

These approaches are supported by academic analysis. Robert Pape's detailed study of suicide bombings from 1980 found that these were politically motivated, not inspired by religion (Pape, 2005). As Mark Juergensmeyer wrote:

Religion ... does not ordinarily lead to violence. That happens only with the coalescence of a peculiar set of circumstances - political, social, and ideological - when religion becomes fused with violent expressions. (Juergensmeyer, 2000)

In any case, it is hard to find an appropriate term to describe the current phenomena. 'Jihadi' terrorism could be a clear title, inasmuch as the term - jihadi - is that which the perpetrators of violence often take themselves. But how can it be right to allow them to do so, when the term means - to the vast majority - the personal struggle to live a virtuous 
life? The term 'Islamist terror' is another variant; but of course it is possible to be Islamist to seek to bring Islamic values and law into the political arena - and not at all committed to violence.

\section{Islam and 'Britishness'}

But there is, in the UK, a strong media and cultural strain of thought that easily equates Islam with terror. Perhaps the foremost exponent of this view is Melanie Phillips. 'It shows very clearly the precise nature of what the civilised world is up against, a war of religion with striking similarities to Nazi ideology and murderous mass hysteria' (Phillips, 2008b). Her other, related, favourite theme is Britishness:

Britain currently seems to be in a state of permanent uproar about its national identity. Home-grown Brits don't seem to know what it is any more, while immigrants flock to these shores in vast numbers to claim it for themselves. (Phillips, 2008a)

There are, she argues, two Britains:

There is the Britain that loves and would defend to the death its own historic national identity - and the Britain that either wants to destroy it or refuses to acknowledge that it is under such threat. And it is the latter which currently wields the levers of power. (Phillips, 2008a)

Of course it is the government, the left, the EU, human rights, multiculturalism, that are on the wrong side of her argument. But how we know that there are two Britains, how we know that the country is falling apart in Philips' view, is essentially focussed on Islam. She argues:

Mr Brown is certainly right to worry that the bonds of Britishness are fraying. But he is actually helping snap them still further, not least in his refusal to hold the cultural line against radical Islamism. (Phillips, 2008a, emphasis added)

And later, 'It is astounding, for example, that the state now pays welfare benefits to the multiple wives of polygamous Muslim men'.

A similar echo - that 'radical Islam' shows how Britain has gone wrong - can be found in an article for the Royal United Services Institute, based on a series of private seminars between a number of luminaries. They found that, in terms of thinking about threats to the United Kingdom,

Islamist terrorism is where people tend to begin. The United Kingdom presents itself as a target, as a fragmenting, post-Christian society, increasingly divided about interpretations of its history, about its national aims, its values and in its political identity. That fragmentation is worsened by the firm self-image of those elements within it who refuse to integrate. This is a problem worsened by the lack of leadership from the majority which in mis-placed deference to 'multiculturalism' failed to lay down the line to immigrant communities, thus undercutting those within them trying to fight 
RENEWAL Vol 17 No. 12009

extremism. The country's lack of self-confidence is in stark contrast to the implacability of its Islamist terrorist enemy, within and without. (Prins and Salisbury, 2008)

Surely the task for progressive politics is to develop a narrative counter to this? Here then is the dilemma in sharp political tones. To describe the terror threat with any term of reference to Islam is to reinforce the 'Britain as broken/divided/failing' narrative set out in parts of the media and amongst some of the institutes. Progressive politics surely should be concerned with solidarity with embattled British identities; be concerned with engaging the legitimate political activity amongst British Muslims (Briggs, 2007); and be engaged with finding acceptable language to describe the nature of contemporary threats to the UK.

\section{Conclusion}

Religion is a potent force in international politics, because religion is for so many a core element of their identity. This is not just obvious in countries such as Pakistan and Iran; it is also true of the United States. Progressive politics in Britain needs to engage more fully with the political dimensions of religion in the ways in which the future of the globe is considered. That involves taking seriously the opportunity for influencing and working with elements of the Christian Right in the United States over global social justice issues. It involves developing approaches and language in relation to Britain's contemporary terrorist threats.

Tony Blair is already there: having completed his own journey from Anglican to Roman Catholic, he launched the 'Faith Foundation' in 2008, and is spending the current academic year teaching on issues of faith and globalisation at Yale University in the United States. It is unlikely, however, that his initiatives will complete all of the work of integrating a consideration of religion into progressive approaches to world affairs. Indeed, given the way in which he is viewed by many communities in the UK over the Iraq war, the opportunity for development under the Blair banner may be limited. But he is right to identify faith as an increasingly crucial dimension of national and international politics that will continue to shape our collective engagements for a long time to come.

Stuart Croft is Professor of International Security at Warwick University, and directs the Economic and Social Research Council's New Security Challenges Programme.

\section{References}

Albright, M. (2006) The Mighty and the Almighty: Reflections on America, God, and World Affairs, London, HarperCollins.

Briggs, R. (2007) 'Who's afraid of the Respect Party?', Renewal 15 (2/3), pp. 89-97.

Buss, D. and Didi, H. (2003) Globalizing Family Values: The Christian Right in International Politics, Minneapolis, University of Minnesota Press.

Cooperman, A. (2005) 'Coming Soon to a Church Near You', Washington Post, 21.10.2005.

Croft, S. (2007) 'Thy Will be Done', International Politics 44 (6), pp. 692-710.

Dionne, E. J. (2006) 'A Shift Among the Evangelicals', Washington Post, 16.06.2006.

Hathut, H. (2007) 'Reflections on Terrorism', Islamophobia.org, 9.04.2007; available at http://www.islamophobia.org/readarticle.php?article_id=142

Juergensmeyer, M. (2000) Terror in the Mind of God: The Global Rise of Religious Violence, Berkeley, University of California Press. 
Mead, W. R. (2006) 'God's Country?', Foreign Affairs 85 (5), pp. 24-44.

National Association of Evangelicals (2004) For the Health of the Nation: An Evangelical Call to

Civic Responsibility, NAE, available at http://www.nae.net/images/civic_responsibility2.pdf

Olson, E. (2003) ‘Is Eric Rudolph a Christian Terrorist?’, Christianity Today weblog, 1.06.2003, available at http://www.christianitytoday.com/ct/2003/juneweb-only/6-2-22.0.html

Pape, R. (2005) Dying to Win: The Strategic Logic of Suicide Terrorism, New York, Random House.

Pew Forum on Religion and Public Life (2008) U.S. Religious Landscape Survey, February, available at http://religions.pewforum.org/reports

Phillips, M. (2008a) 'Britain's broken heart', Daily Mail, 10.03.2008.

Phillips, M. (2008b) 'Fitna', The Spectator, 30.03.2008; available at http://www.spectator.co.uk/melaniephillips/583026/fitna.thtml

Prins, G. and Salisbury, R. (2008) 'Risk, Threat and Security: The case of the United Kingdom' RUSI Journal 153 (1).

Strobel, L. (2005) The Case for a Creator: A Journalist Investigates Scientific Evidence That Points Toward God, Zondervan.

Swift, D. (2004) “"Mark of the Beast” Day Has White House Planning for Rapture', The Swift Report, 28.12.2004; available at http://swiftreport.blogs.com/news/2004/12/white_house_exp.html

Walliss, J. (2007) 'Understanding Contemporary Millenarian Violence', Religious Compass 1 (4), pp. 498-511.

\section{Notes}

1. Security Service (MI5) 'The Threats', at http://www.mi5.gov.uk/output/Page23.html. All web references in this article were accessed during March 2008.

2. Security Service (MI5), at http://www.mi5.gov.uk/output/Page546.html

3. http://www.godhatesfags.com

4. Center for Science and Culture, 'Peer-reviewed \& peer-edited scientific publications supporting the theory of intelligent design (annotated)', at http://www.discovery.org/a/2640

5. Answers Research Journal, at http://www.answersingenesis.org/arj/

6. 'The Harry Potter Series: A Vision of the Antichrist', available at http://www.pawcreek.org/articles_pcm/end_times/harry_potter_antichrist.htm

7. If you fancy defeating the Antichrist, a free copy can be downloaded from http://www.leftbehindgames.com/free/index.html

8. Available at http://www.ropercenter.uconn.edu/cgibin/hsrun.exe/roperweb/pom/pom.htx;start=ipollsearch?TopID=341. Telephone polls taken of between 900 and 1000, so the numbers should be seen as indicative rather than as highly robust. 